Experimental Research

\title{
Effect of postmenopausal hormone treatment on serum lipid profile and coagulation factors
}

\author{
Sinem Beden* \\ Gynaecology and Obstetrics Clinic, Samsun Maternity and Pediatric Hospital, Samsun, Turkey
}

\begin{tabular}{|c|c|}
\hline ARTICLE INFO & ABSTRACT \\
\hline $\begin{array}{ll}\text { Article History } & \\
\text { Received } & 30 / 10 / 2010 \\
\text { Accepted } & 12 / 12 / 2010\end{array}$ & $\begin{array}{l}\text { To assess the effects of different hormone treatment regimes on blood lipids, lipoproteins, } \\
\text { ATIII, fibrinogen in postmenopausal patients. We studied retrospectively } 115 \text { patients who } \\
\text { recieved one of four different estrogen treatment protocols. Of the } 115 \text { patiens; } 25 \text { had }\end{array}$ \\
\hline $\begin{array}{l}\text { * Correspondence to: } \\
\text { Sinem Beden } \\
\text { Denizevleri mh. } 213 \text { sk. 9/13 } \\
\text { Atakum, Samsun, Turkey } \\
\text { e-mail: sinembeden@yahoo.com }\end{array}$ & $\begin{array}{l}\text { received transdermal estradiol patch } 3.9 \mathrm{mg} / \text { week(TD) (Group-1), } 22 \text { patients had received } \\
\text { TD + MPA } 2.5 \text { (Group-2), } 19 \text { patients had received oral CEE } 0.625 \mathrm{mg} \text { /day (Group-3), } 23 \\
\text { patients had received CEE } 0.625 \mathrm{mg} / \mathrm{day}+\text { MPA } 2.5 \mathrm{mg} \text { /day (Group-4), } 26 \text { postmenopausal } \\
\text { patients who had no hormonal treatment composed control group. Plasma cholesterol, lipids, } \\
\text { lipoproteins, ATIII, and fibrinogen levels before and } 6 \text { months after treatment were checked } \\
\text { from their recordings retrospectively. Serum cholesterol level increased in control group, }\end{array}$ \\
\hline $\begin{array}{l}\text { Key Words : } \\
\text { Hormone Replacement Treatment } \\
\text { Menopause } \\
\text { Lipid Profile } \\
\text { Coagulation Factor } \\
\text { Postmenopusal Period }\end{array}$ & $\begin{array}{l}\text { in Group } 2,3 \text {, and } 4 \text { while it increased insignificantly in control group. Serum HDL level } \\
\text { increased significantly only in oral CEE taking Group-3 ( } 24 \% \text { increase). Trigliseride level } \\
\text { significantly decreased in Group-2 }(10.1 \% \text { decrease). Fibrinogen decreased in all treatment } \\
\text { groups, ATIII did not change in treatment groups but increased in control group by } 22.9 \% \text {. } \\
\text { Estrogen alone or in combination with progestin effects plasma lipid levels in a positive } \\
\text { way. It also decreases fibrinogen level that might be protective for CVD. } \\
\text { J. Exp. Clin. Med., 2010; } 27: 99-103\end{array}$ \\
\hline
\end{tabular}

C) 2010 OMU All rights reserved

\section{Introduction}

The decline in circulating estrogen levels at menopause often induces unacceptible symptoms that affect the health and well being of woman. Hormone therapy (both unopposed estrogen and in combination with progestin) is an effective way of treatment for these symptoms (Furness et al., 2009) Even though the estrogen deficiency is treatable, less than $20 \%$ of postmenopausal women use estrogen (Cauley et al., 1990)

Death due to cardiovascular disease (CVD) is 3 times more common in men than women before menopause but it increases in women after menopause (Kannel, 1987). Hormone replacement therapy has been suggested to prevent CVD (Varma et al., 1985; Egeland et al., 1990; Sulvian et al., 1990; Lobo, 1990; Walsh et al., 1991; Wagner et al., 1991; Williams et al, 1992; PaganiniHill and Henderson, 1994; Sack et al., 1994). While some studies have shed doubt in this concept (Herrington et al., 2000; Rossouw et al., 2002) patients studied were of older ages in these studies. Thus uncertinity remains whether current hormone treatment use is beneficial for CVD or may even be harmful (Windler et al., 2007). Most of gynecologists are now bothered by risks of, and are reluctant to use postmenopausal hormone treatment. We conducted this study to see the effects of estrogen, alone or in combination with progestin, in oral or transdermal route, on some CVD risk factors which are plasma lipids and coagulation factors on patients who had just entered menopause.

\section{Experimental procedure}

This study was conducted in Zekai Tahir Burak Child and Maternity Hospital, Ankara, Turkey. Files of a hundred and twenty three postmenopausal patients seen in menopause clinic were reached retrospectively. Ninetyseven of whom had received estrogen and/or progestin, and 26 had received no treatment serving as control group. The effect of hormone therapy on plasma lipids-lipoproteins and coagulation parameters were studied. Eight patients who had not adhere to control visits are excluded from the 
study, and we ended the study with 115 patients.

Climacteric status had been confirmed in all patients by high FSH levels (more than $40 \mathrm{IU} / 1$ ) and very low estradiol levels (less than $20 \mathrm{pg} / \mathrm{ml}$ ). In order to eliminate factors influencing lipid metabolism, we included only patients who were nonsmokers, who had body mass index (BMI) of 30 or less, who did not have diabetes, were not taking medications that effect lipid metabolism or blood pressure, and had normal serum lipid levels. Patients with thyroid dysfunction, history of cardiovascular, renal, hepatic and hematological disease were not included in this study.

Table 1 : Patient treatment groups

\begin{tabular}{ll}
\hline Group 1 (N:25) & Transdermal 17 beta estradiol \\
\hline Group 2(N:22) & Transdermal 17 beta estradiol $+2.5 \mathrm{mg} /$ day MPA \\
\hline Group3(N:19) & Oral concugated equine estrogen $0.625 \mathrm{mg} /$ day \\
\hline Group4(N:23) & Oral concugated equine estrogen $0.625 \mathrm{mg} /$ day $+2.5 \mathrm{mg} /$ day MPA \\
\hline Group 5(N:26) & Control group \\
\hline
\end{tabular}

Blood pressure, weight, and height had been recorded. Mamography, pelvic examination, cervicovaginal smear had been performed for all patiens.

Patiens were divided into 5 groups (Table-1). Group 1 was composed of 25 hysterectomized patients who had transdermal estradiol patch $3.9 \mathrm{mg} /$ week (TD), group 2 was composed of 22 patients who had TD $+2.5 \mathrm{mg}$ MPA daily, group 3 was composed of 19 hysterectomized patients who had oral CEE $0.625 \mathrm{mg} /$ day, group 4 was composed of 23 patients who had CEE $0.625 \mathrm{mg}+2.5 \mathrm{mg}$ MPA and the group 5 was composed of 26 patients who had no therapy. Serum levels of total cholesterol (chol), HDL, LDL, VLDL, trigliseride (TGA), fibrinogen and antithrombin-III (ATIII) had been measured before (basal) and 6 months after treatment.

For measurements, fasting blood had been collected into $3.8 \% \mathrm{Na}$ citrated tubes at 8-10 a.m and santrifuged for 5 minutes at $3000 \mathrm{rpm}$. Plasma had been immediately extracted after santrifugation and stored at -20 degrees for ATIII and fibrinogen measurements. Serum chol and trigliseride levels had been analysed by standardized enzimatic calorimetric techniques. HDL levels had been measured by direct enzimatic methods. Statistical analysis was performed by SPSS 6.0 software. The change of parameters in each treatment group by time was tested by Wilcoxon matched 2 sample test. Intergroup comparisons were performed by oneway ANOVA.

\section{Results}

Patient age, menopause age, menopause duration, and BMI are given in Table-2. There was no difference in terms of these parameters between groups.

Basal HDL levels were not different for 5 groups. After treatment when we compared the routes of estrogen, HDL increased by $24 \%$ in oral CEE group, in TD group it increased only by $1 \%$. When we add MPA to CEE, significant increase of HDL was not detected. There was no difference between groups for basal LDL levels.
After traetment LDL levels decreased significantly in all treatment groups except in group $1(\mathrm{p}<0.05)$. LDL decrease was $9.1 \%$ in group $2,19.08 \%$ in group 3, and $16.5 \%$ in group 4 . (Table-3). When we compared group 1 and 3, LDL decrease was significant in oral CEE group. In TD group LDL did not change after treatment. When we compared group 1 and 2, addition of MPA resulted in decrease of LDL.

Table 2 : Groups' demographic features

\begin{tabular}{|l|l|l|l|l|}
\hline & Menapause age & $\begin{array}{l}\text { Menopause } \\
\text { duration(years) }\end{array}$ & Age of patients & $\begin{array}{l}\text { Body mass } \\
\text { index }\end{array}$ \\
\hline Group 1 & $48.3 \pm 3.1$ & $1.9 \pm 1.2$ & $51.4 \pm 4.6$ & $26.2 \pm 2.5$ \\
\hline Group 2 & $47.9 \pm 2.2$ & $1.9 \pm 1.4$ & $50.5 \pm 4.5$ & $26.5 \pm 3.8$ \\
\hline Group 3 & $47.8 \pm 2.5$ & $1.9 \pm 1.2$ & $51.4 \pm 4.1$ & $25.6 \pm 3.6$ \\
\hline Group 4 & $48.4 \pm 2.2$ & $1.8 \pm 1.5$ & $51.6 \pm 3.7$ & $25.5 \pm 3.1$ \\
\hline Group 5 & $48.2 \pm 2.5$ & $1.8 \pm 1.3$ & $50.9 \pm 4.2$ & $26.2 \pm 4.6$ \\
\hline P & $\mathrm{P}>0.05$ & $\mathrm{P}>0.05$ & $\mathrm{P}>0.05$ & $\mathrm{P}>0.05$ \\
\hline
\end{tabular}

Neither basal nor 6th month VLDL levels were not different between groups including control group. (Table-3)

\begin{tabular}{|c|c|c|c|c|c|c|c|}
\hline & 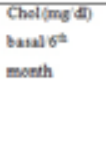 & $\begin{array}{l}\text { HDL(mg/d } \\
1 \text { basal ta } \\
\text { mores }\end{array}$ & $\begin{array}{l}\text { LDL } \\
\text { (mg/d) } \\
\text { banal } \sigma^{\circ} \\
\text { moteth }\end{array}$ & $\begin{array}{l}\text { VLDLimg/d } \\
\text { t) basat os } \\
\text { menth }\end{array}$ & $\begin{array}{l}\text { TGA(mg dl } \\
\text { )banal 6" } \\
\text { month }\end{array}$ & $\begin{array}{l}\text { fibrinogen(mg' } \\
\text { di) basal to } \\
\text { morth }\end{array}$ & $\begin{array}{l}\text { ATIII } \\
\text { mg (dI) } \\
\text { basal } 6 \text { a } \\
\text { metrib }\end{array}$ \\
\hline 1 & $\begin{array}{l}217.8 \\
216.4\end{array}$ & $4 9 . 5 \longdiv { 3 3 . 2 }$ & $\begin{array}{l}138.5 / 136 \\
5\end{array}$ & $27,431.6$ & $\begin{array}{l}138.5 / 143 . \\
9\end{array}$ & $361.6221 .6^{*}$ & 87.5877 .2 \\
\hline$\frac{2}{2}$ & $\begin{array}{l}225.9211 . \\
2 *\end{array}$ & $49.1 / 50.4$ & $\begin{array}{l}144.5 / 131 . \\
2^{*}\end{array}$ & 322228.1 & $\begin{array}{l}139.3 / 125 . \\
\text { s* }\end{array}$ & $337.42755^{*}$ & 84.483 .8 \\
\hline 3 & $\begin{array}{l}225.6213 . \\
2\end{array}$ & $50.5 / 62.1^{*}$ & $\begin{array}{l}152.1 / 123 \\
9 *\end{array}$ & $24.2 / 27.6$ & $\begin{array}{l}123.5 / 137 . \\
1\end{array}$ & $361.5 / 237.1^{*}$ & 88.184 .1 \\
\hline 4 & $\begin{array}{l}232.5 / 212 . \\
5^{*}\end{array}$ & $51.1 / 55.7$ & $\begin{array}{l}152.6127 \\
2^{*}\end{array}$ & 293,315 & $\begin{array}{l}145.1 / 156 \\
0\end{array}$ & $381.4 / 381.4^{*}$ & 88.983 .8 \\
\hline 5 & $\begin{array}{l}222.6247 . \\
3 *\end{array}$ & $43.5 / 43.7$ & $\begin{array}{l}141.6 / 150 \\
2\end{array}$ & $38.2 / 35.4$ & $\begin{array}{l}165.1 / 171 . \\
1\end{array}$ & $355.7 / 355.7$ & $\begin{array}{l}81.4 / 100.1 \\
\text { • }\end{array}$ \\
\hline 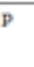 & $\begin{array}{l}30.051<0.0 \\
5\end{array}$ & $\begin{array}{l}>0.05 / 40.00 \\
5\end{array}$ & $\begin{array}{l}30.05 /<0.0 \\
5\end{array}$ & $>0.05>0.05$ & $\begin{array}{l}> \\
0.05 \triangleright 0.05\end{array}$ & $>0.05 /<0.05$ & $\begin{array}{l}30.05 /<0 \\
05\end{array}$ \\
\hline
\end{tabular}

There were no statistically significant difference between groups according to basal TGA levels. After treatment, it decreased significantly $(10.1 \%)$ only in group $2(p<0.005)$. There was no difference between oral and transdermal estrogen groups according to TGA. In both, TGA increased insignificantly. (Table-3). When we look at the effects of MPA, in TD group after addition of MPA, TGA decreased significantly. Basal chol levels were not different between groups ( $>0.05$ ). After 6 month of treatment we detected that patients receiving any kind of hormonal treatment had lower total chol level than control group. There was not any effect of route of estrogen administiration on chol level. But when we add MPA to oral or TD estrogen, chol decrease was significant. In group 2 total cholesterol decreased by $6.3 \%$, and in group 4 it decreased by $8.3 \%$. These decreases were statistically significant $(\mathrm{p}<0.05)$. Decreases in other treatment groups were not statistically significant (Table-3). Chol level in control group was detected to increase significantly $(\mathrm{p}<0.05)$.

There was no difference for basal fibrinogen levels 
between groups. Hormone treatment resulted in decrease of fibrinogen levels in all treatment groups unlike in control group. Fibrinogen levels decreased by $38.7 \%$ in group 1 , by $26.7 \%$ in group 2 , by $34.4 \%$ in group 3 , and by $37.6 \%$ in group 4. In control group, fibrinogen increased by $3 \%$ which was not statistically significant $(\mathrm{p}>0.05)$.

Basal ATIII levels were not different between groups. ATIII levels had not changed significantly with hormone therapy while it had increased significantly after 6 months by $22.9 \%$ in control group.

\section{Discussion}

In this study, we detected that any kind of postmenapousal hormone therapy had resulted in decrease of chol level, and this was statistically significant when $2.5 \mathrm{mg}$ /day MPA had been included in treatment protocol. HDL cholesterol is an important parameter of CVD and HDL cholesterol was detected to increase with hormonal teatment which was statistically significant when oral CEE was preferred for treatment. These findings are smilar to results of study by Walsh BW, 1991. They used 0.625 and $1.25 \mathrm{mg}$ /day CEE in 31 patients for 3 months and detected that $0.625 \mathrm{mg}$ and 1.25. mg CEE decreased LDL cholesterol level by $15 \%$ and $19 \%$, inreased HDL cholesterol by $16 \%$ and $18 \%$, and increased VLDL trigliseride levels by $24 \%$ and $42 \%$ respectively. The authors concluded that estrogen favorably alters LDL and HDL levels that may be protective against aterosclerosis.

Our results are also smilar to those of metaanalysis by Lobo RA, 1991. In this study one year CEE usage was associated with $13 \%$ increase in HDL, $16 \%$ decrease in LDL and $6 \%$ decrease in total cholesterol and an increase in TGA and VLDL.

In ERA (estrogen replacement and atherosclerozis) study 2000, 309 patients with coronary artery disease were randomly divided in to three groups. Placebo (n:105), CEE $0.625 \mathrm{mg} / \mathrm{day}$ (n:100), and CEE $0.625 \mathrm{mg} / \mathrm{day}+2.5 \mathrm{mg} /$ day MPA (n:104). They conducted the study for 3.2 years. A decrease in LDL cholesterol was detected in treatment groups. There was no difference between groups according to CVD progression, and hormone treatment did not effect the CVD adversely.

Alper et al., (2004), conducted a study in post menopausal women receiving oral CEE alone, CEE plus MPA and tibolone on lipid profiles. They investigated the effects of treatment on lipid profile by time ( 2 years). They detected that CEE alone had raised HDL and TGA levels and lowered total cholesterol and LDL levels at the end of two year study period. Addition of MPA to CEE regimen weakened the effect on HDL and TGA, augmented the decrease in total cholesterol and did not effect LDL .

When we compare oral and transdermal routes, HDL cholesterol increased in CEE group and it did not change in transdermal estrogen groups. Our results were similar to that of Adami et al., (1993). The authors detected that transdermal estrogens did not change HDL cholesterol but CEE increased HDL cholesterol significantly.
Gregorio et al., (2002) studied 55 postmenopausal women, 30 of whom had continious 17 beta estradiol and norethisterone acetate for 2 years while 25 women served as control group. They detected that after 2 years of hormonal treatment, total and LDL- cholesterol levels were significantly reduced $(\mathrm{p}<0.05)$. Serum trigliseride and HDL-cholesterol levels did not change significantly.

Fermandes et al., (2008) studied the effects of estradiol and norethisterone on serum lipid level. They carried out a study on 77 postmenopausal women. The patients received one of the three treatment regimes: $2 \mathrm{mg}$ oral micronized estradiol (E2) (n:25), $2 \mathrm{mg}$ oral micronized estradiol $+1 \mathrm{mg}$ oral norethisterone acetate (NETA) (n:28) or placebo (n:24) daily for 6 months. They had carried out evaluations at the baseline and at the end of treatment on lipid and lipoprotein profiles. They reported HDL increase of $15.6 \%$ in E2 group, $2.4 \%$ in E2+NETA and decrease of $6.4 \%$ in placebo group. LDL reduced $9.5 \%$ in E2 and $3.7 \%$ in E2+NETA group and increased $12.1 \%$ in placebo group. They concluded that oral estrogen therapy led to an improvement in lipid profile which is paralelled by the results of our study.

After treatment we detected that TGA level decreased significantly in TD+MPA taking group 2 . Transdermal treatment route decreases TGA with MPA by physiologic effects whereas parenteral estrogen increases TGA by first pass effects. TGAs are important risk factors of CVD. When we compared TD-MPA group with CEEMPA group, we saw that TGAs were decreased in TD-MPA group. Our results are similar to that of Hassa et al., (2007). In their prospective study, they gave $0.625 \mathrm{mg} /$ day CEE or TD $3.9 \mathrm{mg}$ / week to their surgically menopaused patients. They detected that serum TGA levels were significantly more reduced by transdermal estrogen. These results show us how important is to use transdermal estrogen preparations in hiperlipidemic patients once more.

Barbose et al., (2009) carried out a study on 40 postmenopausal women in Brazil. Twenty patients received four 17-beta estradiol -only silastic implants (women without uterus) or four 17-beta estradiol plus one nomegestrol acetate silastic implant (women with uterus). After treatmen period they found that, the incidence of postmenopausal symptoms decreased significantly. No significant decrease in chol $(1.3 \%)$, LDL $(1.1 \%)$, TGA $(1.2 \%)$ occured whereas HDL increased significantly $(2.8 \%)$ during the study in both groups. They concluded that in both transdermal treatment groups postmenopausal symptoms improved, HDL significantly increased and no significant difference in other lipid profiles appeared.

Bayrak et al., (2006) studied the effect of hormone replacement therapy on the levels of serum lipids, apolipoprotein AI, apolipoprotein B and lipoprotein (a) in Turkish postmenopausal women. They gave $0.625 \mathrm{mg}$ $\mathrm{CEE}+2.5 \mathrm{mg}$ MPA daily to 40 patients with intact uterus and only $0.625 \mathrm{mg}$ CEE daily to 20 patients who were hysterectomized. To assess the alterations in lipid and lipoproteins during menopause 45 healty premenopausal 
women were also investigated. They assessed lipid and lipoprotein levels in each subject at the baseline and at the 6 th and 18th months of therapy. In menopause, a shift towards more atherogenic lipid and lipoprotein profiles than those of the premenopausal state was detected just as we detected in our study. Following 18 months of treatment, they saw that both regimens reduced chol levels as compared with the baseline (6.4\% vs. $6.9 \%$ in the $\mathrm{CEE} / \mathrm{MPA}$ and CEE groups respectively). Additionally, the CEE group had a more pronounced increase in HDL than CEE/MPA group (10.3\%vs.8.8\%, respectively), chol and LDL reduced in both groups, TGA reduced in both groups especially in CEE/MPA group. They concluded that both treatment regimes caused positive alterations in the lipid and lipoprotein profiles.

In our study, we detected that in all treatment groups fibrinogen had decreased but ATIII had not changed. ATIII had increased in control group only. Varma TR and his colleques, 1985 studied ATIII levels in 320 climacteric patients. Their study was carried out for 2 years. Of the 320 patients 80 patients received $0.625 \mathrm{mg} /$ day CEE, 82 patients received $1.25 \mathrm{mg} /$ day CEE, 78 received estradiol $1 \mathrm{mg} /$ day, and remaining 80 received estradiol $2 \mathrm{mg} /$ day. They detected no change in ATIII levels in their 4 groups after treatment which is supported by results of our study.

Zegura et al., (2006) studied 112 postmenopausal women. They compared the influence of oral E2 with and without NETA and transdermal E2 on markers of coagulation, fibrinolysis, lipids and lipoproteins. They detected that oral and transdermal E2 decreased fibrinogen but E2+NETA had no effect. The decrease was greater after oral E2 treatment. Oral E2+NETA reduced ATIII.

Venkavaara et al., (2001) studied the effects of oral and transdermal estrogen therapy on markers of coagulation, fibrinolysis, inflamation and serum lipids and lipoproteins in postmenopausal women. They found that oral estradiol changed markers of coagulation towards hypercoagulability. Transdermal estradiol had no effects on any of the parameters of coagulation or fibrinolysis. Their results are not similar to ours. We did not detect any changes towards coagulation.

\section{Acknowledgment}

We concluded that routes of administiration of hormone theraphy on plasma lipids especially on HDL and LDL are important. Oral CEE increases HDL and decreases LDL more than TD route. Also we concluded that MPA decreases chol when added to both routes, decreases TGA when added to only TD route but weakens the effect on HDL when added to oral CEE. With hormone treatment fibrinogen decreases in all treatment groups and all might be protective for CVD.

\section{REFERENCES}

Adami, S., Rossini, M., Zamberland, N., Barteldo, F., Dorizzi, R., Cascio, V.L., 1993. Long term effects of transdermal and oral estrogens on serum lipids and lipoproteins in postmenopausal women. Maturitas. 17, 191-196.

Alper, T., Cetinkaya, M.B., Kökçü, A., Yanık, F.F., Malatyalioglu, E., 2004. Do lipid profiles of postmenopausal women under oral hormone replacement therapy remain stable or reveal a multiphasic course in time? Gynecol. Endocrinol. $18,199-205$.

Barbosa, I.C., Coutinho, E.M., Oladapo, L., Noronha, C.F., Mota, R.L., Lopes, A.C., Lopes, R.C., 2009. An open label study of subdermal implants of estradiol only versus subdermal implants of estradiol plus nomegestrol acetate: effects on symptom control, lipid profile and tolerability. Gynecol. Endocrinol. 25, 269-275.

Bayrak, A., Aldemir, D., Bayrak, T., Corakçı, A., Dursun, P., 2006. The effect of hormone replacement therapy on the levels of serum lipids apolipoprotein AI, apolipoprotein B, lipoprotein A in Turkish postmenopausal women. Gynecol. Obstetrics. 274, 289-296.

Cauley, J.A., Cummings, S.R., Black, D.M., Mascioli, S.R., Seeley, D.G., 1990. Prevelance and determinants of estrogen replacement therapy in elderly women. Am. J. Obstet. Gynecol. 165, 1438-1444.

Egeland, G.M., Kuller, L.H., Matthews, K.A., Kelsey, S.F., Cauley, J., Guzick D., 1990. Hormone replacement therapy and lipoprotein changes during early menopause. Obstet. Gynecol. 76, 776-782.

Fernandes, C.E., Pompei, L.M., Machado, R.B., Ferreira, J.A., Melo, N.R., Peixoto, S., 2008. Effects of estradiol and noretisteron on lipids, insulin resistance and carotid flow. Maturitas. 59, 249-258.

Furness, S., Roberts, H., Marjanbanks, J., Lethaby, A., Hickey, M., Farquhar, C., 2009. Hormone therapy in postmenopausal women and risk of endometrial hyperplasia. Cochrane Database Sys Rev. Apr 15, CD000402.

Gregorio, O., Christoulakos, G., Conidaris, S., Kouskouni, E., Creatsas, G., 2002. Continuous combined replacement therapy in postmenopausal women:effect on plasma lipoproteins, bone mass and the endometrium. Hormones (Athens). 1, 239-244.

Hassa, H., Tanır, M.H., Tekin, B., Öge, T., Kahraman, S., 2007. Lipid profile changes among two groups of surgically menopausal women, using dailly $0.625 \mathrm{mg}$ oral CEE and weekly $3.9 \mathrm{mg}$. TD estrogen patch. J. Turk Soc. Obstet. Gynecol. 4, 47-50.

Herrington, D.M., Reboussin, D.M., Brosnihan, K.B., 2000. Effects of estrogen replacement on the progression of coronary artery atherosclerosis. N. Engl. J. Med. 343, 522-529.

Kannel, W.B., 1987. Metabolic risk factors for coronary heart disease in woman:perspective from the Framingham 
Study. Am. Heart J. 114, 413-419.

Lobo, R.A., 1990. Cardiovascular implications of estrogen replacement therapy. Obstet. Gynecol. 75, 18-25.

Lobo, R.A., 1991. Effects of hormone replacement on lipids and lipoproteins in postmenopausal women. J. Clin. Endocrinol. Metab. 73, 925-930.

Paganini-Hill, A., Henderson, V.W., 1994. Estrogen deficiency and risk of Alzheimers' disease in women. Am. J. Epidemiol.140, 256-261.

Rossouw, J.E., Anderson, G.L., Prentice, R.L., LaCroix, A.Z., Kooperberg, C., Stefanick, M.L., Jackson, R.D., Beresford, S.A., Howard, B.V., Johnson, K.C., Kotchen, J.M., Ockene, J. Writing Group for the Women's Health Initiative Investigator, 2002. Risks and benefits of estrogen plus progestin in healthy postmenopausal women: principal results From the Women's Health Initiative randomized controlled trial. JAMA. 288, 321-333

Sack, M.N., Rader, D.J., Cannon, R., 1994. Estrogen and inhibition of oxidation of low density lipoproteins in postmenopausal women. Lancet. 343, 269-270.

Sullivan, J.M., Vander Zwaag, R., Hughes, J.P., Maddock, V., Kroetz, F.W., Ramanathan, K.B., Mirvis, D.M., 1990. Estrogen replacement and coronary artey disease. Effect on survival in postmenopausal women. Arch. Intern Med. $150,2557-2562$.

Vehkavaara, S., Silveira, A., Hakala-Ala-Pietila, T., Virkamäki, A., Hovatta, O., Hamsten, A., Taskinen, M.R., YkiJärvinen, H., 2001. Effects of oral and transdermal estrogen replacement therapy on markers of coagulation, fibrinolysis, inflamation and serum lipids and lipoproteins in postmenopausal women.Thromb. Haemost. 85, 61925.

Varma, T.R., Patel, R.H., Rosenberg, D., 1985. Effect of hormone replacement therapy on anti-thrombine III activity in postmenopausal women. Int. J. Gynaecol. Obstet. 24, 69-73.

Walsh, B.W., Schiff, I., Rosner, B. ,Greenberg, L., Ravnikar, B., Sacks, F.M., 1991. Effects of postmenopausal estrogen replacement on the concentrations and metabolism of plasma lipoproteins. N. Eng. J. Med. 325, 1196-1204.

Wagner, J.D., Clarkson, T.B., St Clair, R.W., Schvenke, D.C., Shievely, C.A., Adams, M.R., 1991. Estrogen and progestin replacement therapy reduces low density lipoprotein accumulation in the coronary arteries of surgically postmenopausal cynomolgus monkeys. J. Clin. Invest. 88, 1995-2002.

Williams, J.K., Adams, M.R., Herrington, D.M., Clarkson, T.B.,1992. Short term administration of estrogen and vascular responses of atherosclerotic coronary arteries. J. Am. Coll. Cardiol. 20, 452-457.

Windler, E., Zyriac, B.C., Eidenmüller, B., Boeing, H., 2007. Hormone replacement therapy and risk of coronary heart disease. Data from the CORA - study - a case-control study on women with incident coronary heart disease. Maturitas.57, 239-246.

Zegura, B., Guzic-Salobir, B., Sebestjen, M., Keber, I., 2006. The effects of various menopausal hormone therapies on markers of inflamation, coagulation, fibrinolysis, lipids and lipoproteins in healty postmenopausal women. Menopause. 13, 643-650 